doi: 10.17492/vision.v3i1.7070

\title{
Early Thoughts and Preparations for GST in India
}

\author{
M M Sury*
}

\begin{abstract}
The introduction of Goods and Service Tax (GST) has been one of the most ambitious and dynamic tax reforms in the history of India. Recommended first in 2003 by the Task Force on Implementation of the Fiscal Responsibility and Budget Management Act, the implementation of GST has seen many roadblocks since the introduction of the idea. However, it now stands ready to be rolled out after considerable deliberations and addressing of pertinent issues. This paper traces the preparations in India for the introduction of GST, starting from the time when the idea was introduced in the Parliament till after eleven years when it stands ready to be implemented. It is attempt to enable us to appreciate the magnitude of efforts of the policy makers in making India a common dynamic market.
\end{abstract}

Keywords: Goods and Service tax (GST), VAT, Central Sales Tax, Budget.

\subsection{Introduction}

GST is the most ambitious and remarkable tax reform in India in its postIndependence history. Implementing a new tax, encompassing both goods and services, by the Centre and the States in a large and complex federal system, is perhaps unprecedented in modern global tax history. GST was first recommended by the Task Force on Implementation of the Fiscal Responsibility and Budget Management Act, 2003 (Chairman: Vijay Kelkar). The Report of the Task Force observed, "The introduction of the GST at both Central and State levels should be accompanied by the withdrawal of all cascading taxes such as octroi, Central Sales Tax, state level sales taxes, entry tax, stamp duties, telecom license fees, turnover taxes, tax on consumption or sale of electricity, taxes on transportation of goods and passangers etc. This removal of inefficient and distortionary taxes would constitute a major milestone for reforms in Indian public finance".

*Formerly Economic Advisor - Delhi State Finance Commission, Formerly Reader, University of Delhi, Delhi. 
The Central Excise Act and the taxation of services by the Finance Act, 1994, will be subsumed under the central goods and services tax. This should be implemented through a legislation which may be named Indian Goods and Services Act. The States will need to simultaneously introduce corresponding legislation for taxation of goods and services which will subsume their existing State-level cascading taxes. Under this proposed grand bargain, the States obtain revenues from taxation of services, and from access to GST on imports. More importantly, India would obtain the full efficiencies of a single national VAT, while retaining a federal structure." (Government of India, 2004)

The idea of moving towards the GST was first mooted by the then Union Finance Minister Shri P. Chidambaram in his Budget for 2006-07. Initially, it was proposed that GST would be introduced from 1st April, 2010. The Finance Minister observed, "It is my sense that there is a large consensus that the country should move towards a national level Goods and Services Tax (GST) that should be shared between the Centre and the States. I propose that we set April 1, 2010 as the date for introducing GST. World over, goods and services attract the same rate of tax. That is the foundation of a GST. People must get used to the idea of a GST." (Government of India, 2006-07)

\subsection{Roadmap for GST}

While declaring its intention to introduce GST from April 1, 2010, the Central Government had indicated that the Empowered Committee (EC) of State Finance Ministers $^{2}$ would work with the Central Government to prepare a road map for the introduction of GST. Hence, EC-which had formulated the design of State level VAT - prepared a report on a Model and Road Map for GST. Pursuant to this, on May 10, 2007, EC set up a Joint Working Group consisting of representatives of the EC and the Government of India. This Joint Working Group got itself divided into three Sub-Groups and had several rounds of internal discussions as well as interaction with experts and representatives of Chambers of Commerce and Industry. On the basis of these discussions and interaction, the Sub-Groups submitted their reports which were then integrated and consolidated into the report of Joint Working Group (November 19, 2007).

This report was discussed in detail in the meeting of the EC on November 28, 2007, and the States were also requested to communicate their observations on the report in writing. On the basis of these discussions in the EC and the written observations, certain modifications were considered necessary and were discussed with the representatives of the Department of Revenue, Ministry of Finance, Government of India. With the modifications duly made, a final version of the views of EC resulted in the preparation of 
A Model and Road Map for Goods and Service Tax in India (April 30, 2008). The model and roadmap, while recommending that a dual GST be put in place, also provided preliminary views on the Central and State taxes to be subsumed within the GST.

The model detailed the operational issues which needed to be addressed, including the number of rates, exemptions and exclusions from GST, as well as the treatment of inter-state transactions. The roadmap outlined the legal and administrative steps which needed to be taken in order to comply with the April 1, 2010 deadline.

These views of EC were then sent to the Government of India, and the comments of Government of India were received on December 12, 2008. These comments were duly considered by the EC (December 16, 2008), and it was decided that a Committee of Principal Secretaries/Secretaries of Finance/Taxation and Commissioners of Trade Taxes of the States should be set up to consider these comments, and submit their views.

The Committee held detailed deliberations on January 5-6, 2009, and submitted its recommendations to the Empowered Committee. The Empowered Committee considered these recommendations in its meeting held on January 21, 2009 and accepted them in- principle.

\subsection{First Discussion Paper on GST}

As a follow-up of this in-principle acceptance, a Working Group consisting of the concerned officials of the State Governments was formed who, in association with senior representatives of Government of India, submitted their recommendations in detail on the structure of GST.

After taking into account a detailed view on the recommendations of the Working Group of officials and other related matters, EC released the First Discussion Paper on Goods and Services Tax in India (November 10, 2009, for discussion with industry, trade, agriculture and people at large. The comments of Government of India on the proposed design of GST were sent to the Empowered Committee in January 2010. A joint group of officers was constituted to prepare draft Constitutional Bill, Central GST legislation, model State GST legislation and rules required to introduce GST. To operationalize the GST, the Constitution (One Hundred and Fifteenth Amendment) Bill was introduced in the Lok Sabha in March 2011 to enable Parliament and State Legislatures to make laws for levying GST on every transaction of supply of goods or services or both. Some goods, namely crude petroleum, diesel, petrol, aviation turbine fuel, natural gas and alcohol were not to come under the purview of the GST.

The Discussion Paper was divided into 4 sections. Section 1 gave a brief reference to the process of introduction of VAT by the Centre and the States and also indicated the precise points where there was a need for further improvement. This section also showed 
how GST could bring about this improvement. With this as the background and justification for GST, section 2 then described the process of preparation for GST. Thereafter, section 3 presented in detail the comprehensive structure of the GST model.

\subsection{Major Recommendations of the First Discussion Paper (FDP)}

(i) Dual Goods and Services Tax Model for India: FDP took note of the significant administrative issues involved in designing an effective GST model in a federal system with the objective of having an overall harmonious structure of rates. Together with this, it emphasized the need for upholding the powers of Central and State Governments in their taxation matters. Further, it underlined the need to propose a model that would be easily implementable, while being generally acceptable to stakeholders.

A dual GST structure with defined functions and responsibilities of the Centre and the States was recommended. An appropriate mechanism that would be binding on both the Centre and the States would be worked out whereby the harmonious rate structure along with the need for further modification could be upheld, if necessary with a collectively agreed constitutional amendment.

Salient features of the model recommended by FDP were as follows:

1. GST should have two components - one levied by the Centre (referred to as Central GST), and the other levied by the States (referred to as State GST). Rates for Central GST and State GST would be prescribed appropriately, reflecting revenue considerations and acceptability. This dual GST model would be implemented through multiple statutes (one for CGST and SGST statute for every State). However, the basic features of law such as chargeability, definition of taxable event and taxable person, measure of levy including valuation provisions, basis of classification etc. would be uniform across these statutes as far as practicable.

2. Central GST and the State GST would be applicable to all transactions of goods and services made for a consideration except the exempted goods and services, goods which remain outside the purview of GST and the transactions which are below the prescribed threshold limits.

3. Central GST and State GST are to be paid to the accounts of the Centre and the States separately. It would have to be ensured that account-heads for all services and goods would have indication whether it relates to Central GST or State GST (with identification of the State to whom the tax is to be credited).

4. Since the Central GST and State GST are to be treated separately, taxes paid against the Central GST shall be allowed to be taken as input tax credit (ITC) for the Central GST and could be utilized only against the payment of Central GST. The same principle would be applicable for the State GST. A taxpayer or exporter would have 
to maintain separate details in books of account for utilization or refund of credit. Further, the rules for taking and utilization of credit for the Central GST and the State GST would be aligned.

5. Cross utilization of ITC between the Central GST and the State GST would not be allowed except in the case of inter-State supply of goods and services under the IGST mode.

6. Ideally, the problem related to credit accumulation on account of refund of GST should be avoided by both the Centre and the States except in the cases such as exports, purchase of capital goods, input tax at higher rate than output tax etc. where, again refund/adjustment should be completed in a time bound manner.

7. To the extent feasible, uniform procedure for collection of both Central GST and State GST should be prescribed in the respective legislation for Central GST and State GST.

8. Administration of the Central GST to the Centre and for State GST to the States was recommended. This would imply that the Centre and the States would have concurrent jurisdiction for the entire value chain and for all taxpayers on the basis of thresholds for goods and services prescribed for the States and the Centre.

9. FDP noted that existing threshold prescribed in different State VAT Acts-below which VAT was not applicable - varied from State to State. A uniform State GST threshold across States was desirable and, therefore, it was recommended that a threshold of gross annual turnover of Rs.10 lakh — both for goods and services for all the States and Union Territories - may be adopted with adequate compensation for the States (particularly, the States in North-Eastern Region and Special Category States) where lower threshold had prevailed in the VAT regime. Keeping in view the interest of small traders and small-scale industries and to avoid dual control, the threshold for Central GST for goods may be kept at Rs.1.5 crore and the threshold for Central GST for services may also be appropriately high.

10. Composition/compounding scheme for the purpose of GST should have an upper ceiling on gross annual turnover and a floor tax rate with respect to gross annual turnover. In particular, there should be a compounding cut-off at Rs. 50 lakh of gross annual turn over and a floor rate of 0.5 percent across the States. The scheme should also allow option for GST registration for dealers with turnover below the compounding cut-off.

11. Taxpayer would need to submit periodical returns, in common format as far as possible, to both the Central GST authority and to the concerned State GST authorities. 
12. Each taxpayer would be allotted a PAN-linked taxpayer identification number with a total of 13/15 digits. This would bring the GST PAN-linked system in line with the prevailing PAN-based system for Income tax, facilitating data exchange and taxpayer compliance.

Keeping in mind the need of tax payer's convenience, functions such as assessment, enforcement, scrutiny and audit would be undertaken by the authority which is collecting the tax, with information sharing between the Centre and the States.

(ii) Central and State Taxes to be subsumed under GST: The various Central, State and Local levies were examined to identify their possibility of being subsumed under GST. While identifying these levies, the following principles were kept in mind:

1. Taxes or levies to be subsumed should be primarily in the nature of indirect taxes, either on the supply of goods or on the supply of services.

2. Taxes or levies to be subsumed should be part of the transaction chain which commences with import/manufacture/production of goods or provision of services at one end and the consumption of goods and services at the other.

3. Subsumation should result in free flow of tax credit in intra and inter-State levels.

4. Taxes, levies and fees that are not specifically related to supply of goods and services should not be subsumed under GST.

5. Revenue fairness for both the Union and the States individually would need to be attempted.

On application of the above principles, FDP recommended that the following Central taxes should be, to begin with, subsumed under the GST: Central excise duty, Additional excise duties, Excise duty levied under the Medicinal and Toiletries Preparation Act, Service tax, Additional customs duty, commonly known as countervailing duty (CVD), Special additional duty (SAD) of customs, surcharges, and cesses.

The State taxes and levies, that were recommended for subsumation under GST were: VAT/sales tax, Entertainment tax (unless it is levied by the local bodies), Luxury tax, Taxes on lottery, betting and gambling, State cesses and surcharges in so far as they relate to supply of goods and services, and Entry tax not in lieu of octroi.

(iii) Purchase Tax: Some of the States were getting substantial revenue from purchase tax and, therefore, they were not in favour of its subsumation under GST while majority of the States were of the view that no such exemptions should be given. The difficulties of the foodgrains producing States and certain other States were appreciated as substantial revenue was being earned by them from purchase tax and it was, therefore, felt that in case purchase tax had to be subsumed then adequate and continuing compensation should be provided to such States. This issue was discussed in consultation with the Government of India. 
(iv) Tax on tobacco products, petroleum products and items containing alcohol: Alcoholic beverages would be kept out of the purview of GST. Sales tax/VAT can be continued to be levied on alcoholic beverages as per the existing practice. Excise duty, which is presently being levied by the States may also not be affected. Tobacco products would be subjected to GST with ITC. Centre may be allowed to levy excise duty on tobacco products over and above GST without ITC. As regards petroleum products, it was decided that the basket of petroleum products, i.e. crude, motor spirit (including ATF) and HSD would be kept outside GST as is the prevailing practice in India. Sales tax could continue to be levied by the States on these products with prevailing floor rate. Similarly, Centre could also continue its levies. A final view whether natural gas should be kept outside the GST would be taken after further deliberations.

(v) Inter-state transactions of goods and services: IGST model for taxation of inter-State transaction of goods and services would be adopted. The scope of IGST Model is that Centre would levy IGST which would be CGST plus SGST on all inter-State transactions of taxable goods and services with appropriate provision for consignment or stock transfer of goods and services. The inter-State seller would pay IGST on value addition after adjusting available credit of IGST, CGST, and SGST on his purchases. The Exporting State would transfer to the Centre the credit of SGST used in payment of IGST. The Importing dealer would claim credit of IGST while discharging his output tax liability in his own State. The Centre would transfer to the importing State the credit of IGST used in payment of SGST. The relevant information would also be submitted to the Central Agency which would act as a clearing house mechanism, verify the claims and inform the respective governments to transfer the funds.

(vi) GST Rate Structure: FDP suggested a two-rate structure-a lower rate for necessary items and goods of basic importance and a standard rate for goods in general. It also recommended a special rate for precious metals and a list of exempted items. For upholding of special needs of each State as well as a balanced approach to federal flexibility, and also for facilitating the introduction of GST, it was discussed whether the exempted list under VAT regime including goods of local importance be retained in the exempted list under State GST in the initial years. It was also deliberated whether the Government of India may adopt, to begin with, a similar approach towards exempted list under the CGST.

The States were of the view that for CGST relating to goods, the Government of India may also have a two rate structure, with conformity in the levels of rate under the SGST. For taxation of services, there may be a single rate for both CGST and SGST. The exact value of the SGST and CGST rates, including the rate for services, would be made known duly in course of appropriate legislative actions. 
(vii) Zero rating of exports: Exports would be zero-rated. Similar benefits may be given to Special Economic Zones (SEZs). However, such benefits would only be allowed to the processing zones of the SEZs. No benefit to the sales from an SEZ to Domestic Tariff Area (DTA) should be allowed.

(viii) GST on imports: The GST will be levied on imports with necessary Constitutional Amendments. Both CGST and SGST should be levied on import of goods and services into the country. The incidence of tax would follow the destination principle and the tax revenue in case of SGST would accrue to the State where the imported goods and services are consumed. Full and complete set-off would be available on the GST paid on import on goods and services.

(ix) Special Industrial Area Scheme: After the introduction of GST, the tax exemptions, remissions etc. related to industrial incentives should be converted, if at all needed, into cash refund schemes after collection of tax, so that the GST scheme on the basis of a continuous chain of set-offs is not disturbed. Regarding Special Industrial Area Schemes, it was clarified that such exemptions, remissions etc. would continue up to legitimate expiry time both for the Centre and the States. Any new exemption, remission etc. or continuation of earlier exemption, remission etc. would not be allowed. In such cases, the Central and the State Governments could provide reimbursement after collecting GST.

(x) Compensation during Implementation of GST: Despite the sincere attempts made by the Empowered Committee on the determination of GST rate structure, revenue neutral rates, it was difficult to estimate accurately as to how much the States would gain from service taxes and how much they would lose on account of removal of cascading effect, payment of input tax credit and phasing out of CST. In view of this, it would be essential to provide adequately for compensation for loss that might emerge during the process of implementation of GST for the next 5 years. The payment of this compensation will need to be ensured in terms of special grants to be released to the States duly in every month on the basis of neutrally monitored mechanism.

\subsection{Constitutional Requirements and Measures}

The Constitution provides for delineation of power to tax between the Centre and States. Prior to the enactment of Constitution (One Hundred and First Amendment) Act, 2016, while the Centre was empowered to tax services and goods up to the production stage, the States had the power to tax sale of goods. The States did not have the power to levy a tax on the supply of services while the Centre did not have power to levy tax on the sale of goods. Thus, the Constitution did not vest express power either in the Central 
or State Government to levy a tax on the supply of goods and services. Moreover, the Constitution also did not empower the States to impose tax on imports. Therefore, it was essential to have constitutional amendments for empowering the Centre to levy tax on sale of goods and States for levy of service tax and tax on imports and other consequential issues.

In March 2011, the Constitution (One Hundred and Fifteenth Amendment) Bill, 2011 was introduced in Parliament to enable the levy of GST. However, the Bill lapsed with the dissolution of the 15th Lok Sabha. Subsequently, in December 2014, the Constitution (One Hundred and Twenty Second Amendment) Bill, 2014 was introduced in the Lok Sabha which was passed on May 6, 2015.

Rajya Sabha passed the same Bill with 9 amendments on August 3, 2016. Lok Sabha passed the modified Bill on August 8, 2016 approving all the 9 amendments by the Rajya Sabha. After getting approval of half of the States, it was sent to the President for his assent which was given on September 8, 2016. The Constitution (One Hundred and Twenty-second Amendment) Bill 2014 was notified as the Constitution (One Hundred and First Amendment) Act, 2016.

Suitable legislation for the levy of GST (Central GST Bill, Integrated GST Bill and State GST Bills) drawing powers from the Constitution would need to be passed by the Parliament and the State Legislatures. Unlike the Constitutional Amendment which requires 2/3rd majority, the GST Bills would need to be passed by a simple majority. Obviously, the levy of the tax can commence only after the GST law has been enacted by the Parliament and respective Legislatures.

Also, unlike the State VAT, the date of commencement of this levy would have to be synchronized across the Centre and the States. This is because the IGST model cannot function unless the Centre and all the States participate simultaneously.

\subsection{Phasing out of Central Sales Tax (CST)}

To prepare for the implementation of GST, the Central Government had also begun a phased reduction of CST. The rate of CST was brought down from 4 percent to 2 percent as a precursor to rolling out GST. CST was one of the taxes which were subsumed under GST. CST, which was an origin-based tax, was inconsistent with GST which is a destination-based value added tax.

While making preparation for GST, it was also necessary to phase out the CST, because it did not carry any set-off relief and there was a distortion in the VAT regime due to export of tax from one State to other State. The Empowered Committee accordingly took a decision to phase out CST on the understanding with the Centre 
that - since phasing out of CST would result in a loss of revenue to the States on a permanent basis - an appropriate mechanism to compensate the States for such loss would be worked out. The rate of CST has already been reduced to 2 percent and will be phased out with effect from the date of introduction of GST on the basis of such GST structure which - with necessary financial support to the States-should adequately compensate for the loss of the States on a permanent basis.

Hoping for the early implementation of the GST, the Finance Minister Shri P. Chidambaram in his 2013-14 Budget Speech observed, "Hon'ble Members will recall that I had first mentioned the Goods and Services Tax (GST) in the Budget speech for 2007-08. At that time, it was thought that GST could be brought into effect from 1.4.2010. Alas, that was not to be, although all States swear by the benefit of GST. However, my recent meetings with the Empowered Committee of State Finance Ministers has led me to believe that the State Governments-or, at least, the overwhelming majority - are agreed that there is need for a Constitutional amendment; there is need for State Governments and the Central Government to pass a GST law that will be drafted by the State Finance Ministers and the GST Council; and there is need for the Centre to compensate the States for loss due to the reduction in the CST rate. I hope we can take this consensus forward in the next few months and bring to this House a draft Bill on the Constitutional amendment and a draft Bill on GST. Hope inspires courage. I propose to take the first decisive step by setting apart, in the Budget, a sum of Rs. 9,000 crore towards the first instalment of the balance of CST compensation. I appeal to the State Finance Ministers to realise the serious intent of the Government to introduce GST and come forward to work with the Government and bring about a transformational change in the tax structure of the country".

In his Budget Speech to the Parliament on June 10, 2014, the Finance Minister Shri Arun Jaitley made the following observations regarding GST, "The debate whether to introduce a Goods and Services Tax (GST) must now come to an end. We have discussed the issue for the past many years. Some States have been apprehensive about surrendering their taxation jurisdiction; others want to be adequately compensated. I have discussed the matter with the States both individually and collectively. I do hope we are able to find a solution in the course of this year and approve the legislative scheme which enables the introduction of GST. This will streamline the tax administration, avoid harassment of the business and result in higher revenue collection both for the Centre and the States. I assure all States that government will be more than fair in dealing with them".

In his Budget Speech to the Parliament on February 28, 2015, the Finance Minister Shri Arun Jaitley observed on GST as follows, "We need to revive growth and investment to 
ensure that more jobs are created for our youth and benefits of development reach millions of our poor. We need an enabling tax policy for this. I have already introduced the Bill to amend the Constitution of India for Goods and Services Tax (GST) in the last Session of this august House. GST is expected to play a transformative role in the way our economy functions. It will add buoyancy to our economy by developing a common Indian market and reducing the cascading effect on the cost of goods and services. We are moving in various fronts to implement GST from the next year".

Currently, the hope is that GST will be implemented from April 1, 2017.

\subsection{Milestones in the Journey of GST}

GST was introduced in the country after an 11-year long journey since it was first proposed by the Union Finance Minister Shri P. Chidambaram in his 2006-07 budget speech on February 28, 2006. A brief chronology outlining the major milestones on the proposal for introduction of GST in India is given in Table 1.

Table 1: Major Milestones in the Journey of GST

\begin{tabular}{|l|l|}
\hline Date/month/year & \multicolumn{1}{|c|}{ Event } \\
\hline 2003 & $\begin{array}{l}\text { Vijay Kelkar Task Force on Implementation of the Fiscal Responsibility } \\
\text { and Budget Management Act, 2003 suggestes a comprehensive Goods } \\
\text { and Services Tax (GST) based on VAT principle. }\end{array}$ \\
\hline $\begin{array}{l}\text { February 28, } \\
2006\end{array}$ & $\begin{array}{l}\text { Finance Minister Shri P. Chidambaran in his Budget Speech for the year } \\
\text { 2006-07 moots a proposal to introduce a National Level Goods and } \\
\text { Services Tax (GST) by April 1, 2010. Since the proposal involved } \\
\text { reform/restructuring of not only indirect taxes levied by the Centre but } \\
\text { also the States, the responsibility of preparing a Design and Road Map } \\
\text { for the implementation of GST is assigned to the Empowered Committee } \\
\text { (EC) of State Finance Ministers. EC duly prepares a report on a Model } \\
\text { and Road Map for GST. }\end{array}$ \\
\hline May 10,2007 & $\begin{array}{l}\text { EC sets up a Joint Working Group consisting of representatives of the EC } \\
\text { and the Government of India for an in-depth study of the report prepared } \\
\text { by it. }\end{array}$ \\
\hline $\begin{array}{l}\text { November 19, } \\
2007\end{array}$ & $\begin{array}{l}\text { The Joint Working Group submits its report based on discussions and } \\
\text { interactions with stakeholders }\end{array}$ \\
\hline $\begin{array}{l}\text { November 28, } \\
2007\end{array}$ & \begin{tabular}{l} 
EC discusses in detail the report of the Joint Working Group. \\
\hline April 30, 2008
\end{tabular} \\
\hline
\end{tabular}




\begin{tabular}{|c|c|}
\hline & $\begin{array}{l}\text { and Road Map for Goods and Services Tax in India. } \\
\text { The model detailed the operational issues which needed to be addressed, } \\
\text { including the number of rates, exemptions and exclusions from GST, as } \\
\text { well as the treatment of inter-state transactions. } \\
\text { The roadmap outlined the legal and administrative steps which needed to } \\
\text { be taken in order to comply with the April 1,2010 deadline. }\end{array}$ \\
\hline $\begin{array}{l}\text { December 12, } \\
2008\end{array}$ & $\begin{array}{l}\text { EC receives the comments of the Government of India on the above- } \\
\text { mentioned document. }\end{array}$ \\
\hline $\begin{array}{l}\text { December 16, } \\
2008\end{array}$ & $\begin{array}{l}\text { EC takes note of the comments of the Government of India and appoints } \\
\text { a Committee to consider these comments in detail. }\end{array}$ \\
\hline January 5-6, 2009 & $\begin{array}{l}\text { The Committee holds detailed deliberations and submits its } \\
\text { recommendations to EC. }\end{array}$ \\
\hline January 21, 2009 & $\begin{array}{l}\text { EC considers the recommendations of the Committee and accepts them } \\
\text { in-principle. It forms a Working Group of concerned officials to submit } \\
\text { their recommendations in detail on the structure of GST. }\end{array}$ \\
\hline $\begin{array}{l}\text { November } 10 \text {, } \\
2009\end{array}$ & $\begin{array}{l}\text { Based on the recommendations of the Working Group, EC releases the } \\
\text { First Discussion Paper on Goods and Services Tax in India. }\end{array}$ \\
\hline March 2011 & $\begin{array}{l}\text { Constitution (One Hundred and Fifteenth Amendment) Bill, } 2011 \text { is } \\
\text { introduced in the Parliament. The Bill lapses with the dissolution of the } \\
\text { 15th Lok Sabha. }\end{array}$ \\
\hline December 2014 & $\begin{array}{l}\text { Constitution (One Hundred and Twenty-second Amendment) Bill, } 2014 \\
\text { is introduced in the Lok Sabha. }\end{array}$ \\
\hline May 6, 2015 & The above Bill is passed by the Lok Sabha. \\
\hline August 3, 2016 & The above Bill is passed by the Rajya Sabha with 9 amendments. \\
\hline August 8, 2016 & $\begin{array}{l}\text { Lok Sabha passes the modified Bill approving all the } 9 \text { amendments by } \\
\text { the Rajya Sabha. }\end{array}$ \\
\hline $\begin{array}{l}\text { September 8, } \\
2016\end{array}$ & $\begin{array}{l}\text { After being approved by half of the States, President gives his assent to } \\
\text { the Bill. The Constitution (One Hundred and Twenty-second } \\
\text { Amendment) Bill } 2014 \text { is notified as the Constitution (One Hundred and } \\
\text { First Amendment) Act, } 2016 \text {. }\end{array}$ \\
\hline April 1, 2017 & Target date for the launch of GST. \\
\hline
\end{tabular}

If the Value Added Tax (VAT) was a major improvement over the pre-existing Central excise duty at the national level and the sales tax system at the State level, then GST is a further significant breakthrough towards a comprehensive indirect tax reform in the country. It would go a long way in making India a common, integrated and dynamic market. 


\section{Endnotes}

1. While presenting the budget for 2010-11 to the Parliament on February 26, 2010, Minister of Finance Shri Pranab Mukherjee, rescheduled the time limit for the implementation of GST and expressed the hope that GST, along with the Direct Tax Code (DTC), would be introduced from April 1, 2011.

2. The Empowered Committee of State Finance Ministers (EC) was originally set up on 17th July, 2000 by the Government of India with the Hon'ble State Finance Ministers of West Bengal, Karnataka, Madhya Pradesh, Maharashtra, Punjab, Uttar Pradesh, Gujarat, Delhi and Meghalaya as members with an objective to monitor the implementation of uniform floor rates of sales tax by States and Union territories, to monitor the phasing out of the sales-tax based incentive schemes, to decide milestones and methods of States to switch over to VAT and to monitor reforms in the Central Sales Tax system existing in the country. Subsequently, Hon'ble State Finance Ministers of Assam, Tamil Nadu, Jammu \& Kashmir, Jharkhand and Rajasthan were also notified as the members of the Empowered Committee. On 12th August, 2004, the Government of India decided to reconstitute the Empowered committee with Hon'ble State Finance/Taxation Ministers of all States as its members. Recently, in order to strengthen the EC, Thirteenth Finance Commission recommended that a grant of Rs 30 crore be made to EC, so that they can pursue GST related research work and enhance capacities. Amount of Rs 30 crore has accordingly been released to EC for creating a corpus of for this purpose.

\section{References}

Government of India. (2004). Ministry of Finance, Report of the Task Force on Implementation of the Fiscal Responsibility and Budget Management Act, 2003(Chairman: Vijay Kelkar), July 16, p. 7.

Government of India. (2006-07). Ministry of Finance, Budget Speech of the Finance Minister, 2006-07.

Government of India. (2013-14). Ministry of Finance, Budget Speech of the Finance Minister, 2013-14.

Government of India. (2014-15). Ministry of Finance, Budget Speech of the Finance Minister, 2014-15.

Government of India. (2015-16). Ministry of Finance, Budget Speech of the Finance Minister, 2015-16, para 96. 